\title{
Dietary supplementation with Cyperus esculentus $L$ (tiger nut) tubers attenuated atherosclerotic lesion in apolipoprotein $E$ knockout mouse associated with inhibition of inflammatory cell responses
}

\author{
${ }^{1}$ Mohamed Labib Salem, ${ }^{2}$ Mohsen Zommara and ${ }^{3} \mathrm{~K}$. Imaizumi \\ ${ }^{1}$ Department of Surgery, Medical University of South Carolina, Charleston, SC 29425 \\ ${ }^{2}$ Department of Dairy Science, Faculty of Agriculture, Tanta University, Kafr El-Scheikh 33516, Egypt \\ ${ }^{3}$ Department of Bioscience and Biotechnology, Kyushu University, Fukuoka, 812-8581, Japan
}

\begin{abstract}
Atherosclerosis is a pathological process, where recruitment of mononuclear cells results in the growth of fibro-fatty plaques. Apolipoprotein E (ApoE) is a legend for the uptake of lipoproteins, and deficiency of ApoE leads to the accumulation of low-density lipoprotein. Utilizing $\mathrm{ApoE}^{-/-}$mouse, which spontaneously develop atherosclerosis on low-fat chow diets, the present study showed that feeding these mice on a diet supplemented with the whole tubers of Cyperus esculentus L (tiger nut) resulted in attenuation of the development of atherosclerotic lesions. The anti-atherosclerotic effect was associated with a decrease in the number of monocytes, macrophages and dendritic cells in blood, and the expression of IL-2R $\alpha$ and LFA-1 by these cells. Further, in vitro proliferation of blood and spleen cells from tiger nut-fed $\mathrm{ApoE}^{-{ }_{-}^{-}}$mice showed lower proliferation in responses to ConA and LPS, a $\mathrm{T}$ and $\mathrm{B}$ cell mitogen, respectively. Further, in vitro treatment of blood and spleen cells with water or ethanol extracts of tiger nut markedly increased their proliferation in response to ConA. Collectively, these data indicate that ingredients of tiger nut tubers exhibit anti-inflammatory properties upon inflammation, and immunostimulatory effects in immunocompetent hosts.
\end{abstract}

Key words: Tiger nut; ApoE ${ }^{-/-}$mice; Atherosclerosis; Immunity; LFA-1; CD40L

\section{INTRODUCTION}

Atherosclerosis is a pathological process, which gives rise to fatty streak lesions within arteries that are foci of macrophage $(\mathrm{M} \phi)$-derived foam cells trapped beneath the endothelial-cell lining of the artery [1]. Continued recruitment of mononuclear cells and proliferation and migration of smooth muscle cells results in the growth of fatty streak lesions into larger fibro-fatty plaques. Recent studies highlighted the role of inflammatory mediators and the cells of the innate and adaptive immune response in the initiation, growth and rupture of atherosclerotic plaques [2]. Viewing this form of vascular pathology as a modified form of chronic inflammation suggests new avenues for therapeutic interventions in atherosclerosis and cardiovascular diseases [2].

Apolipoprotein E (ApoE) is an important legend for the uptake of lipoproteins by many receptors in the low-density lipoprotein (LDL) receptor gene family. Deficiency of ApoE leads to the accumulation of cholesterol ester enriched particles [3, 4]. ApoEdeficient mice $\left(\mathrm{ApoE}^{-l}\right)$ are generated by gene targeting to disrupt ApoE gene in embryonic stem cells. These animals have elevated serum cholesterol levels (around $500 \mathrm{mg} / \mathrm{dl}$ ), and spontaneously develop severe atherosclerosis on low-fat chow diets, which is apparent in mice of only 10 weeks of age [5]. ApoE ${ }^{-/-}$mice fed a high fat diet $(21 \%$ fat and $0.15 \%$ cholesterol) have serum cholesterol levels of approximately $2,000 \mathrm{mg} / \mathrm{dl}$ and larger lesions at any given time [6]. Thus, $\mathrm{ApoE}^{-1-}$ mouse is an innovative preclinical mouse model to study the initiation, progression and prevention of atherosclerosis.

A larger number of plants and their isolated constituents have been shown to modulate immunity [7, 8]. Some medicinal plants have been shown to exert anti-inflammatory, anti-stress and anti-cancer effects by modulating the immune functions [9-12]. Cyperus esculentus $\mathrm{L}$, known as tiger nut or chufa, plant is a member of the grass family Cyperaceae to which nut sedge weeds also belong. Chufa tubers are daily ingredients of the diet of many people in North Africa and Spain [13]. In North Africa, the tubers are consumed in their natural form or after being soaked in water for some hours. In Spain the tubers are consumed mainly as a drink called locally "horchata de chufa" (chufa milk). This plant was originally native to the Mediterranean region but its cultivation has now spread to many other warm countries [14]. The tubers of this plant are known by several names, such as tiger nut, earthnut, earth almond, rush nut, and chufa. The tubers are consumed either a nut or grated, and used for ice cream and beverage making. The tubers contain about $25 \%$ oil, which are resistant to peroxidation, $50 \%$ digestible carbohydrates, $4 \%$ protein and $9 \%$ crude fiber $[15,16]$. Very little data is available about the nutritional value of whole chufa tubers.

Corresponding Author: $\quad$ Dr. Mohamed Labib Salem, Section of Surgical Oncology, Department of Surgery, Medical University of South Carolina, Charleston, SC 29425; e-mail: salemm@musc.edu 
We found in this study that feeding $\mathrm{ApoE}^{-/-}$mice with whole tiger nut tuber significantly inhibited the atherosclerotic lesions in these mice. Thus, we analyzed its immunoregulatory effect on the numbers and functions of immune cells in atherosclerotic $\mathrm{ApoE}^{-/-}$ mice. In addition, we investigated the direct effects of tiger nut extracts on the immune cells in vitro. For our knowledge, the results of the present study are the first to show that tiger nut can modulate the number, proliferation and activation of inflammatory cells, ameliorating the inflammatory responses. These results provide a new avenue for the natural remedy-based treatment of inflammatory diseases, such as atherosclerosis, by the active ingredients of this plant.

\section{MATERIALS AND METHODS}

MICE: 6-7 weeks old C57BL/6 mice, and $\mathrm{ApoE}^{-/-}$ mice, on C57BL/6 background, were purchased from Laboratory (Bar Harbor, ME). Mice were housed individually in a temperature-controlled room at 22$25^{\circ} \mathrm{C}$ and maintained under specific pathogen-free condition on a $12 \mathrm{~h}$ light_dark cycle. Mice were provided with food and water ad libitum, and were used at 8 weeks of age with an average weight of $20 \mathrm{~g}$..

REAGENTS AND ANTIBODIES: RPMI 1640 medium (Gibco, Grand Island, UT) was supplemented with $10 \%$ heat-inactivated fetal calf serum (HyClone, Logan, UT), $5 \times 10^{-5}$ M 2-mercaptoethanol, $2 \mathrm{mM} \mathrm{L-}$ glutamine, $10 \mathrm{mM}$ HEPES, $100 \mu \mathrm{g} / \mathrm{ml}$ gentamicine and $0.2 \%$ sodium biocarbonate. Concavanline A (Con-A) and lipopolysaccharide (LPS) (Sigma) were reconstituted in PBS. Anti-CD3, anti-CD4-FITC, antiCD8-cychrome, anti-CD11a-PE, anti-CD11b-APC, anti-CD11c-PE, Anti-CD16/CD32, anti-CD25, antiCD40 FITC, anti-CD40L FITC, anti-CD62L-PE, antiCD69 PE and anti-B220-FITC were purchased from Pharmingen (San Diego, CA).

\section{PREPARATION OF TIGER NUT POWDER AND} THEIR EXTRACTS: Tiger nut (chufa) tubers (Cyperus esculenuts L) were obtained from the local market at Tanta city, Egypt. For the preparation of tiger nut powder, the tubers were cleaned, washed and dried in a stream of hot air for an hour. The dried tubers were milled using a laboratory electric mill to pass through a 40-mesh sieve. The milled tubers were extracted by shaking it with 3 volumes of hexane for one hour three times to remove the oil. The defatted milled tubers were dried in a dissector under vacuum. The water extract was obtained by stirring the dry defatted milled tubers with 7 volumes of distilled water at room temperature for 12 hours. The suspension was centrifuged at 3000 rpm for 10 minutes and the supernatant was filtered through cotton cloth and then through Whatman filter paper No. 1 under vacuum. The ethanol extract was prepared by shaking the dry defatted milled tubers with 5 volumes of $80 \%$ of ethanol for 12 hours at room temperature. The suspension was allowed to stand for 15 minutes and filtered through cotton cloth. The extraction was repeated twice with the solid residue and the combined filtrate was centrifuged at $3000 \mathrm{rpm}$ for $10 \mathrm{~min}$. The supernatant was concentrated by removing ethanol under reduced pressure in a rotary evaporator at $40^{\circ} \mathrm{C}$. The water and ethanolic extracts were freezedried.

CONTROL AND EXPERIMENTAL DIETS: ApoE ${ }^{-}$ ${ }^{1-}$ mice were fed AIN-93G [17] diet supplemented with $25 \%$ whole powder of chufa tubers (experimental diet) or without (control diet) for 11 weeks. The average chemical composition $(\mathrm{g} / 100 \mathrm{~g})$ of chufa tubers includes starch 34 , oil 25 , protein 8 , sucrose 16 , fiber 10 and others 7 (Table I). The diets were designed to contain equal amounts of energy (about $3606 \mathrm{Kcal} / \mathrm{Kg}$ diet). Mice were arranged into two groups with 11 mice (6 male and 5 female mice) per group. The animals were housed individually, and the body weight and food intake were recorded every other day.

Table I. Composition of experimental diets $(\mathrm{g} / \mathrm{kg})$

\begin{tabular}{lcc} 
Ingredients & Control diet & Tiger nut diet \\
\hline Chufa tubers (whole) & - & 250 \\
Casein & 200 & 180 \\
Olive oil & 100 & 37.5 \\
Vitamin mixture & 10 & 10 \\
Mineral mixture & 3.5 & 3.5 \\
Choline bitartrate & 2.5 & 2.5 \\
L-cystine & 3.0 & 3.0 \\
Cellulose & 50 & 50 \\
$\alpha$-corn starch & 132 & 132 \\
Corn starch & 367 & 239 \\
& & \\
\hline
\end{tabular}

MORPHOMETRIC EVALUATION OF ATHEROSCLEROSIS: The aorta was perfused with 50ml PBS ( $\mathrm{pH}$ 7.4) via a cannula inserted in the right ventricle, allowing unrestricted efflux from an incision in the vena cava. Perfusion was continued with $50 \mathrm{ml}$ of $10 \%$ neutral formalin buffer solution at $\mathrm{pH} 7.4$ (Wako Pure Chemicals, Osaka, Japan), and the heart was dissected. The bulk of the fat and tissue adhering to the adventitia was separated. To determine the crosssectional lesion volume, hearts containing aortic roots were processed for quantitative atherosclerosis assay of the aortic root using a modification of the methods described by [18]. Briefly, the heart was cut along a plane between the tip of the two atria and the top half was embedded in paraffin. Consecutive sections $(10 \mu \mathrm{m}$ thick) were prepared from the ascending aorta to the aortic sinus until the aortic tissue disappeared. The sections were mounted on glass slide and stained with elastic Van Gieson and hematoxylin [19]. Five sections of each heart were selected for intimal area determination; the first and most distal sections to the heart were taken where the aoertic valve cusp was 
barely discernible. From this section, moving to the base of the heart, every other $10 \mu \mathrm{m}$ section was also photographed. The intimal area was measured by capturing the image using a video camera mounted on an Olympus LX70 light microscope and analyzed using Adobe Photoshop and Nih image/68K 1.57 software (National institute of Health, Bethesda, MD, USA) on a Power Macintosh Computer. The mean intimal area was calculated for each animal, and subsequently for each group.

\section{PREPARATION OF MONONUCLEAR} LEUKOCYTES: After food had been withheld for 6 hours, the mice were killed by withdrawing blood from the right ventricle under anaesthesia with an intraperitoneal injection of sodium pentobarbital ( $5 \mathrm{mg} / \mathrm{g}$ body weight). Spleens were harvested and a single cell suspension was made by pressing the organ with the rough ends of glass slides in RPMI medium. Red blood cells in blood and splenocytes were lysed and the samples were overlaid on Ficoll to obtain mononuclear cells.

FLOW CYTOMETRY: Peripheral blood lymphocytes (PBLs) and splenocytes were stained with the indicated $\mathrm{mAb}$ to assess the number and activation status of different populations of inflammatory cells including Tcells (CD4 and CD8), B cells, macrophages (M $\phi)$ and dendritic cells. Single-cell suspensions were prepared, and $1 \times 10^{6}$ cells were treated with anti-CD16/CD32 for $5 \mathrm{~min}$ on ice to block non-specific binding. The cells were then stained with the indicated mAb. After a 30min incubation on ice, the cells were washed twice, and resuspended in $0.3 \mathrm{ml}$ of $0.5 \% \mathrm{BSA}, 0.02 \%$ sodium azide solution. Dead cells were excluded by staining with propidium iodide and cells were analyzed by 2- or 3-flow cytometry using the CellQuest software package (Becton Dickinson, San Jose, CA).

IN VITRO PROLIFERATION ASSAY: After 11 weeks of feeding, the mice were sacrificed and peripheral blood and spleens were harvested under sterile conditions. For in vitro proliferation assay, PBLSs or splenocytes $\left(5 \times 10^{6} / \mathrm{ml}\right)$ from naïve or $\mathrm{ApoE}^{-/-}$ mice, fed on the control or experimental diet were seeded $(100 \mu \mathrm{l})$ in quadruplicates into 96-well flatbottom plates in serum-free RPMI 1640 medium. Cells were then stimulated with ConA $(10 \mu \mathrm{g} / \mathrm{ml})$ or LPS $(5 \mu \mathrm{g} / \mathrm{ml})$. Cells obtained from naïve mice were treated immediately with or without different concentrations of water or ethanol extracts of tiger tubers. The cultured cells were incubated for $48 \mathrm{hr}$ at $37^{\circ} \mathrm{C}$ in a $5 \% \mathrm{CO}_{2}$, $37^{\circ} \mathrm{C}$ and $5 \% \mathrm{CO}_{2}$ and pulsed with $37 \mathrm{kBq}$ of ${ }^{3} \mathrm{HdThd}$ 6 hours before harvesting. The cultures were harvested, and the incorporation of ${ }^{3} \mathrm{H}$ was counted with the Beta Plate System (Pharmacia LKB Biot, Uppsala, Sweden). The data was recorded as counts per minute (CPM).
STATISTICS: Numerical data obtained from each experiment were expressed as mean $\pm \mathrm{SD}$, and statistical differences between the experimental groups were assessed using the Student's $t$-test. $P$ values less than 0.05 were considered to indicate statistical significance.

\section{RESULTS}

FEEDING TIGER NUT DIMINISHED THE
ATHEROSCLEROTIC LESIONS IN APOE-/MICE: ApoE ${ }^{-/-}$mice were fed for 11 weeks on control or the experimental diet, sacrificed and the aorta was perfused with PBS via a cannula inserted in the right ventricle, the heart was dissected, and the crosssectional lesion volume was determined to quantify the atherosclerotic lesion of the aortic root. As shown in Fig. 1, feeding on the experimental diet significantly decreased the atherosclerotic lesions in both males and females; the effects were slightly higher in males than females. This experiment was repeated three times with similar results. These data indicate to the antiinflammatory properties of tiger nut tuber.

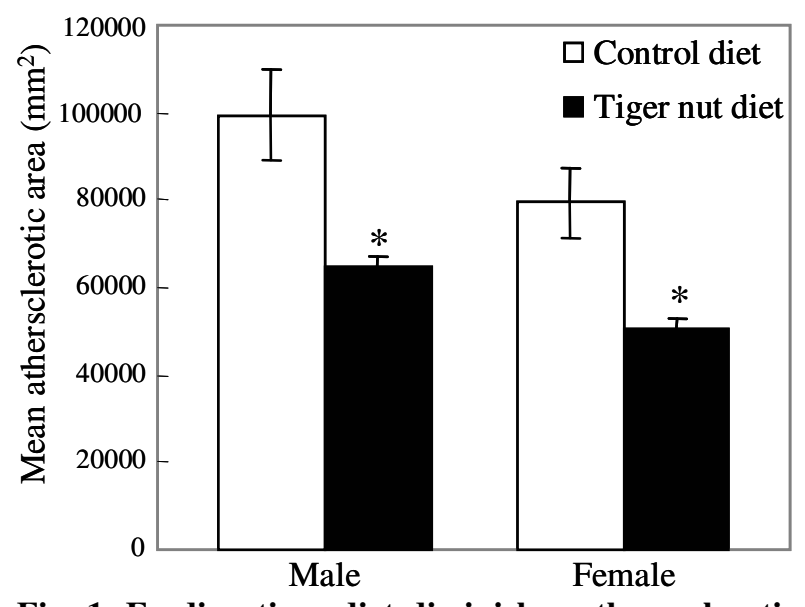

Fig. 1. Feeding tiger diet diminishes atherosclerotic lesions. ApoE-/- ( $\mathrm{n}=6 /$ group) mice were fed for 11 weeks on control or the experimental diet. Then, mice were sacrificed and the atherosclerotic lesion of the aortic root was determined by histological examination.

\section{FEEDING TIGER NUT DECREASES FREQUENCY OF INFLAMMATORY CELLS IN PBLs: Because development of atherosclerotic lesions in $\mathrm{ApoE}^{-/-}$mice is mediated by accumulation of inflammatory cells into the inflammatory lesions in blood, we analyzed the number and phenotype of these cells in the peripheral pool. Thus, $\mathrm{ApoE}^{-/-}$mice were fed for 11 weeks on control or the experimental diet, sacrificed, and fresh PBLs were prepared for phenotypic analysis by flow cytometry. Significant decreases in the levels of dendritic cells $\left(\mathrm{CD} 11 \mathrm{c}^{+}\right)$and proinflammatory monocytes $\left(\mathrm{CD} 11 \mathrm{~b}^{+}\right.$and $\left.\mathrm{CD} 14^{+}\right)$were found in PBLs of the tiger nut-fed $\mathrm{ApoE}^{-{ }^{-}}$mice compared to control diet-fed ApoE ${ }^{-/-}$mice (Fig. 2A).}


Feeding mice on the experimental diet, however, had no effect on the number of B cells $\left(\mathrm{B} 220^{+}\right)$and T-cells $\left(\mathrm{CD}^{+}\right)$including their helper $\left(\mathrm{CD} 4^{+}\right)$and suppressor $\left(\mathrm{CD}^{+}\right)$subsets (Fig. 2B). In spleens, feeding mice with the experimental diet had no effect on the number of $\mathrm{M} \phi$, dendritic cells, B cells, total T-cells or CD4+ and CD8+ T-cell subsets (data not shown). We further analyzed the expression of the activation markers on the PBLs and spleen by flow cytometry. We found that feeding $\mathrm{ApoE}^{-/-}$mice on the experimental diet markedly decreased the expression of CD11a (LFA-1) in the PBLs, however it had no effect on the expression of other activation markers including CD40, CD40L and CD69 (Fig. 3A). By analyzing the activation markers on spleen cells, we found that feeding a tiger nut diet did not show significant effect on the expression of CD69, CD40, CD40L (Fig. 3B). Tiger nut diet, however, markedly decreased the expression of the early activation marker CD25 (IL-2R $\alpha$ ) on both CD4+ and CD8+ T cells (Fig. 3B).
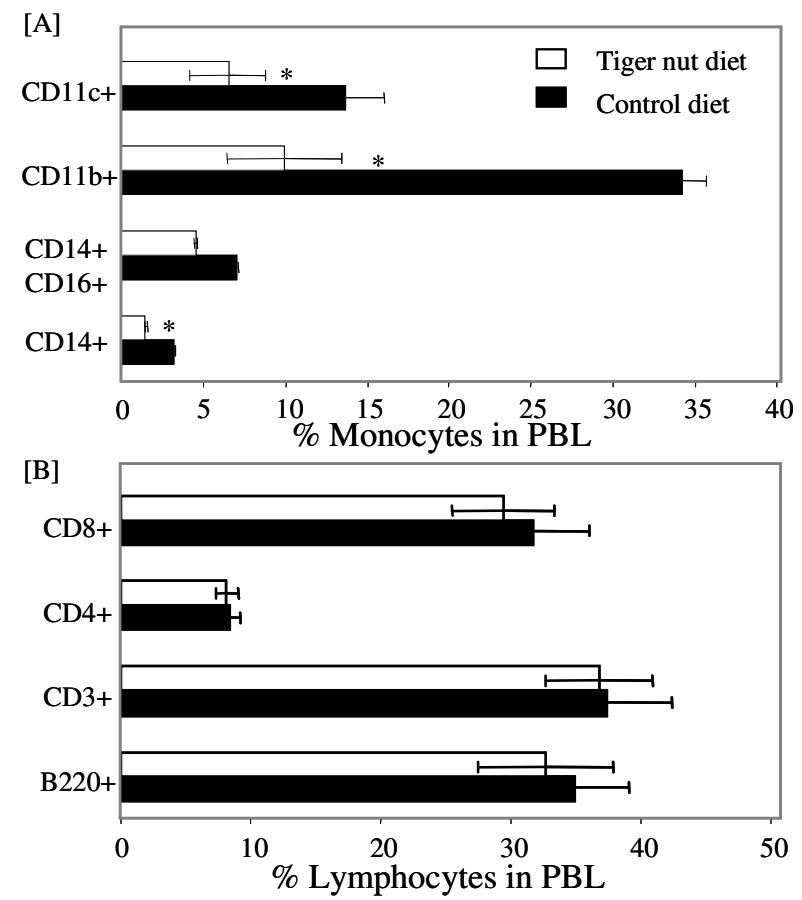

Fig. 2. Feeding tiger diet decreases the number of monocytes in PBLS. ApoE ${ }^{-/-}$mice were sacrificed as in Fig. 1. PBLS were prepared and dendritic cells (CD11c+), M $\phi(\mathrm{CD} 11 \mathrm{~b}+)$ and monocytes (CD14+) (A); and total T-cells (CD3+), helper Tcells (CD4+), cytotoxic T-cells (CD8+) and B cells (B220+) (B) were determined by 2-color flow cytometry after staining with specific antibodies. *, $P<0.01$.

$\begin{array}{lcrl}\text { FEEDING TIGER } & \text { NUT INHIBITED IN } & \text { VITRO } \\ \text { PROLIFERATION } & \text { OF } & \text { PBLS } & \text { AND }\end{array}$ SPLENOCYTES: The results described above showed that feeding $\mathrm{ApoE}^{-/-}$mice on the experimental diet decreased inflammatory cell activation in the peripheral pool (PBLs and spleen). Then, we asked if such effect was coincided with alteration in functions of inflammatory cells. To this, ApoE ${ }^{-/-}$mice were fed on a control or an experimental diet for 11 weeks. Then, mice were sacrificed and PBLs and splenocytes were harvested to assess their proliferation in vitro. Cells were cultured with or without ConA or LPS, which induces proliferation of $\mathrm{T}$ and $\mathrm{B}$ cells, respectively, for 48 hours and the cell proliferation was assessed by thymidine uptake. We found that proliferation of PBLs and splenocytes from mice fed on the experimental diet in response to ConA was significantly lower than the proliferation of cells from the mice fed on the control diet (Fig. 4A). The decrease in the proliferation in response to ConA was more pronounced in PBLS than in splenocytes. A differential response of PBLs and splenocytes was observed in response to LPS; feeding on the experimental diet increased proliferation of PBLs in response to LPS (Fig. 4B), while decreased the response of splenocytes (Fig. 4B).
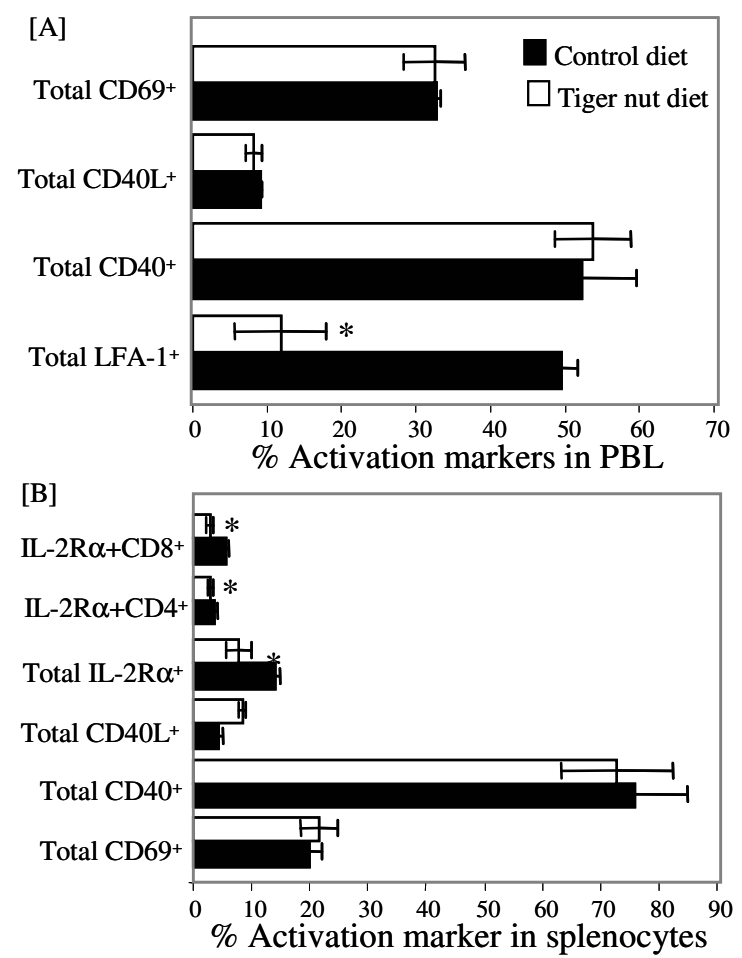

Fig. 3. Feeding tiger nut diet downregulated LFA-1 and IL-2R $\boldsymbol{\alpha}$ expression. ApoE ${ }^{-/-}$mice were fed and sacrificed as described in Fig. 1. After 11 weeks of feeding, the mice were sacrificed and PBLs (A) and spleens (B) were harvested and processed for the expression of different activation markers by flow cytometry after staining with specific antibodies. ${ }^{*}, p<0.01$.

\section{DIRECT EFFECT OF TIGER NUT EXTRACTS ON THE PHENOTYPE OF PBLS AND SPLENOCYTES: To test if the effect observed on the surface markers of the immune cells of the experimental diet mice is mediated by a direct effect; an}


in vitro experiment was performed. Because the immune status in $\mathrm{ApoE}^{-/-}$mice might not be normal, the in vitro experiments were done utilizing cells from wild type B6 mice. PBLs and splenocytes from wild type naïve B6 mice were treated in vitro for $48 \mathrm{hr}$ with or without $200 \mu \mathrm{g} / \mathrm{ml}$ of either water or ethanol extract of tiger nut tubers, then their phenotypic analysis was performed. The treatment had no effect on the number of monocytes $\left(\mathrm{CD} 11 \mathrm{~b}^{+}\right)$, dendritic cells $\left(\mathrm{CD} 11 \mathrm{c}^{+}\right), \mathrm{B}$ cells $\left(\mathrm{B} 220^{+}\right)$and cytotoxic $\left(\mathrm{CD}^{+}\right)$or helper $\left(\mathrm{CD} 4^{+}\right) \mathrm{T}-$ cells (data not shown). By analyzing the expression of the activation markers, the treatment only decreased the expression of CD40L (Fig. 5), while had no effect on the expression of CD40L (Fig. 5); the effects of water extract were more pronounced than the effects of ethanol extract.



Fig. 4. Feeding tiger nut diet inhibited proliferation of T lymphocytes. ApoE ${ }^{-/-}$mice were fed a control or experimental diet. After 11 weeks, mice were sacrificed and $5 \times 10^{5}$ PBLs or spleen were stimulated with $10 \mu \mathrm{g} / \mathrm{ml}$ ConA or $5 \mu \mathrm{g} / \mathrm{ml}$ LPS for $48 \mathrm{hrs}$, then cell proliferation was assessed by ${ }^{3} \mathrm{H}$ uptake assay. ${ }^{*}, p<0.05, * *, p<0.01$.

\section{IN VITRO EXPOSURE OF SPLENOCYTES TO TIGER NUT INCREASED THEIR}

PROLIFERATION: Then we analyzed effect of in vitro treatment with different concentrations of water and ethanol extracts of tiger nut tubers on the proliferation of spleen cells in response to ConA and LPS. Both extracts at doses of 125,250 and $500 \mu \mathrm{g} / \mathrm{ml}$, induced marked increases in the proliferation of splenocytes when stimulated with ConA or LPS (Fig.
$6 \mathrm{~A}$ and $\mathrm{B})$. Of note, the effects of water extract were higher than the effects of ethanol extract. Moreover, the effects of water and ethanol extracts were more pronounced when the cells were stimulated with Con-a than when stimulated with LPS (Fig. 6A and B), indicating that $\mathrm{T}$ cells are more responsive than $\mathrm{B}$ cells to tiger nut extracts. Taken together, these results indicate that tiger nut tubers may enhance the immune status of immunocompetent hosts.

\section{DISCUSSION}

Using $\mathrm{ApoE}^{-/-}$mice, which are prone to develop atherosclerosis, we have found that feeding these mice on a diet supplemented with the whole tiger nut tubers exerted anti-atherosclerotic effects. Specifically, the size of the atherosclerotic lesions markedly decreased in both male and female mice fed on the tiger nut diet. By investigating the immunomodulatory effects of tiger nut on $\mathrm{ApoE}^{-/-}$mic, we showed here that feeding $\mathrm{ApoE}^{-}$ ${ }^{1}$ mice on a diet containing tiger nut induced reduction in the number, activation and proliferation of the inflammatory cells. These findings indicate that the anti-atherosclerotic effects of tiger nut are mediated through modulating the quantity and quality of the inflammatory cells participating in the development of atherosclerosis in $\mathrm{ApoE}^{-/-}$mice. Interestingly, however, we found that ethanol and water extracts of tiger nut increased the proliferative response of $\mathrm{T}$ - and $\mathrm{B}$ lymphocytes of naïve mice. Taken together, these results indicate that tiger nuts induce differential immunomodulatory effects on inflammatory cells and naïve cells, inhibiting the first and enhancing the latter.

Recently, ApoE ${ }^{-/-}$mouse has been used as a model to study the initiation, progression, and prevention of atherosclerosis [20]. ApoE ${ }^{-/-}$mice show elevated levels of serum cholesterol and spontaneously develop severe atherosclerosis when fed on low-fat chow diets [21, 22]. In the present study, we used $\mathrm{ApoE}^{-/-}$mice to investigate the impact of feeding tiger nut on the development of atherosclerosis. We found that feeding $\mathrm{ApoE}^{-/-}$mice on a tiger nut-supplemented diet significantly decreased the establishment of atherosclerosis in these mice. Then, we utilized this model to define the mechanisms of the observed antiatherosclerotic effect of tiger. Thus, $\mathrm{ApoE}^{-/-}$mice were fed a control or experimental diet for 11 weeks. Such feeding regimen induced selective decreases in the number of non-specific cells in PBLs including M $\phi$ and dendritic cells (Fig. 1A). These cells play crucial roles in the development of the disease [23, 24]. A key role for $\mathrm{M} \phi$ in atherogenesis was reported by analysis of op/op osteopetrotic mice, which have a naturally occurring mutation in the gene encoding monocyte-M $\phi$ colony-stimulating factor (M-CSF) and has reduced numbers of $\mathrm{M} \phi[25]$. Atherosclerosis is reduced 70$90 \%$ in op/op and $\mathrm{ApoE}^{-/-}$animals fed a western-style diet containing $21 \%$ fat and $0.2 \%$ cholesterol. This 
result implies that there is a major role for $\mathrm{M} \phi$ in this widely studied animal model of atherosclerosis. Thus, our findings indicate that the anti-inflammatory effect of tiger nut might be mediated by decreasing recruitment of $\mathrm{M} \phi$ to PBLs.

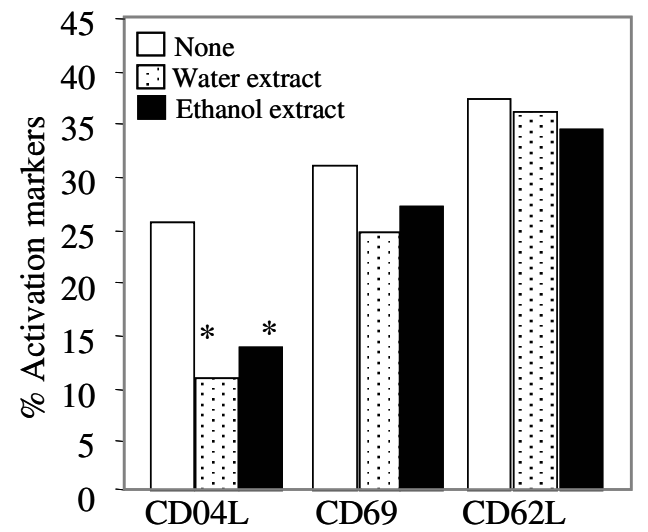

Fig. 5. In vitro treatment of PBLs with tiger nut extracts decreased their expression of CD40L. Naïve $5 \times 10^{5} \mathrm{PBLs} /$ well were stimulated in vitro with $5 \mu \mathrm{g} / \mathrm{ml}$ LPS for $48 \mathrm{hrs}$ with or without (200 $\mu \mathrm{g} / \mathrm{ml})$ water and ethanol extract. Cultured cells were then washed and stained with anti-CD40L Ab and analyzed by flow cytometry. ${ }^{*}, p<0.05$.

Recruitment of inflammatory cells into inflammatory lesions is a crucial step in the initiation and progression of the immune response [26]. This process is mediated by the expression of adhesion molecules, such as LFA-1, by the inflammatory cells, and ICAM-1 and VCAM-1 by the endothelial cells [26]. Such adhesion molecules are known to tether the circulating inflammatory cells to the endothelial cell surface to facilitate their entry into the vessel wall [26, 27]. LFA-1 is usually up-regulated after specific or non-specific inflammation, mediating recruitment of the inflammatory cells into the inflammatory foci [26]. Several reports have shown that not only the number of $\mathrm{M} \phi$ is crucial for the development of atherosclerosis, but also their activation status [28]. One potential mechanism that might mediate the inhibitory effect of tiger nut on the inflammatory response is the alteration of trafficking of the inflammatory cells. Although we have not extensively studied the modulation by tiger nut on trafficking of the inflammatory cells, our results show that tiger nut significantly decreased their activation as reflected by the decrease in their expression of LFA-1. LFA-1 is upregulated after specific or non-specific inflammation to mediate recruitment of inflammatory cells into the inflammatory foci [26]. Therefore, the decrease in the expression of LFA-1 after feeding with tiger nut tubers may explain its inhibitory effects on the number of inflammatory cells in Apo- $\mathrm{E}^{-/-}$mice, coinciding with amelioration of the atherosclerotic lesion in Apo- $\mathrm{E}^{-/-}$mice. In support of our hypothesis, it has been found recently that statins, which possess potent anti-atherosclerotic effects [29], selectively inhibit LFA-1 binding activities [27].

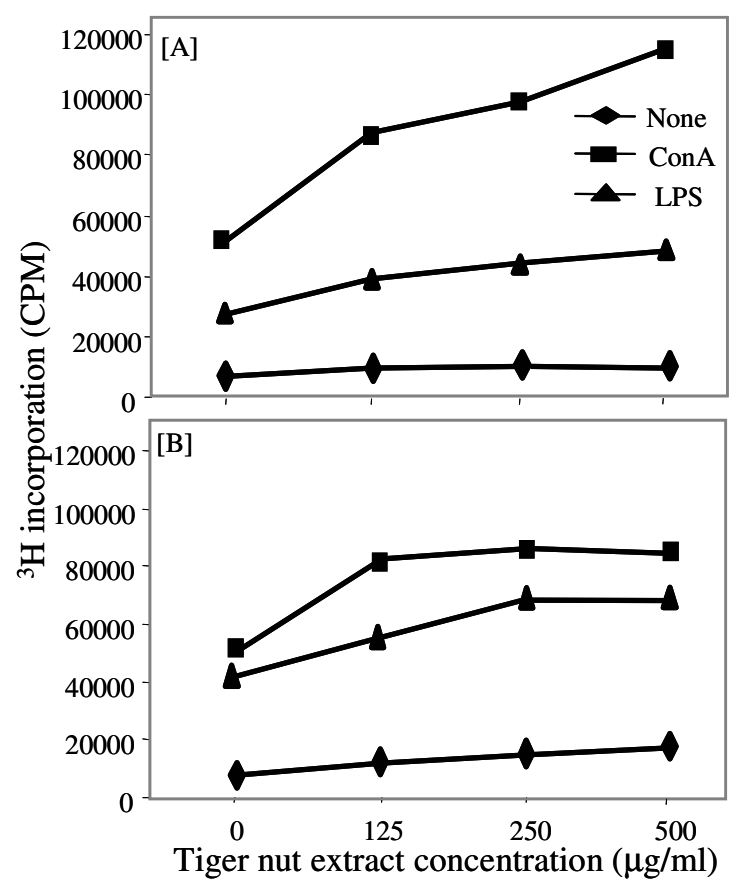

Fig. 6. In vitro treatment of splenocytes with tiger nut water extract enhanced their proliferation. Naïve B6 mice were sacrificed and $5 \times 10^{5}$ spleen cells/well were stimulated for $48 \mathrm{hr}$ with none, $10 \mu \mathrm{g} / \mathrm{ml}$ Con-a, or $5 \mu \mathrm{g} / \mathrm{ml}$ LPS in the presence or absence of $200 \mu \mathrm{g} / \mathrm{ml}$ water (A) or ethanol (B) extracts of tiger nut. Then, cell proliferation was assessed as in Fig. 6. ${ }^{*}, p<0.01$.

Several reports have shown that $\mathrm{T}$ cells are also involved in the course of atherosclerosis [30-35]. The majority of $\mathrm{T}$ cells in atherosclerotic lesions are $\mathrm{CD} 4^{+}$, and the cytokines produced by these cells could have a profound influence on $M \phi$ biology within the atherosclerotic lesion. The direct roles of $\mathrm{T}$ and $\mathrm{B}$ cells have been investigated in $A p o E^{-/} / L d l r^{--}$mice in which the recombination activating genes (RAG) 1 and RAG2 recombinase genes have been knocked out. Such double knockout mice show hypercholesterolaemia and no functional T or B cells [36]. These studies show that the rate of atherosclerotic lesion development in these animals is reduced by $>50 \%$ at early time points. However, the absence of an adaptive immune response does not protect animals from developing atherosclerosis in the presence of high levels of plasma cholesterol over long periods [36]. In the present study, we analyzed the impact of feeding with tiger nut on the number and activation of lymphocytes, including $\mathrm{CD} 4^{+}$ and $\mathrm{CD}^{+} \mathrm{T}$ cells and $\mathrm{B}$ cells. We found that although feeding $\mathrm{ApoE}^{-/-}$mice diet supplemented with tiger nut slightly decreased $\mathrm{CD} 8^{+} \mathrm{T}$ cell number; it had no effect on the number of CD4+ $\mathrm{T}$ - and B-lymphocytes. 
Interestingly however it decreased the expression of IL$2 \mathrm{R} \alpha$. IL-2R $\alpha$ is a marker for early $\mathrm{T}$ cell activation, thus its expression levels might predict the onset of the inflammatory responses in atherosclerosis [35]. By analyzing the expression of IL-2R $\alpha$ on $\mathrm{CD}^{+}$and $\mathrm{CD} 8^{+}$ cells, we found that its expression decreased only on $\mathrm{CD} 8^{+} \mathrm{T}$ cells.

CD40/CD40L interaction is an important mediator of inflammation within the atherosclerotic plaque [3739]. Activated $T$ cells in atherosclerotic plaques express the CD40L. Ligation of CD40 ${ }^{+}$on endothelial cells and $\mathrm{M} \phi$, induces expression of a range of molecules that have important roles in atherogenesis and plaque rupture, including cytokines, chemokines, growth factors, matrix metalloproteinases and procoagulants. Blockade of CD40L signaling in $\mathrm{Ldll}^{-/}$mice using neutralizing antibodies, reduced lesion formation, with a marked reduction in lipid and $\mathrm{M} \phi$ content [40]. We found that feeding tiger nut selectively decreased the expression of CD40L on lymphocytes, which might mediate the anti-atherosclerotic effect of tiger nut. Our findings further support the notion that the antiatherosclerotic effect of tiger nut is mediated by acting on the inflammatory lymphocytes. We found significant reductions in the proliferation of $\mathrm{T}$ and $\mathrm{B}$ cells of tiger nut-fed $\mathrm{ApoE}^{-/-}$mice in response to in vitro stimulation with ConA or LPS, respectively. Such decrease in the proliferation of $\mathrm{T}$ and $\mathrm{B}$-lymphocytes might have a direct inhibitory effect on the development of atherosclerotic lesions and/or indirectly through suppression of $\mathrm{M} \phi$ activation.

Our findings discussed above reveal that feeding a diet supplemented with tiger nut can decrease both the number and activation of the inflammatory cells during the course of atherosclerosis. However, these finding do not reflect the effect of tiger nut on the lymphocytes in healthy immune cells. In this regard, our in vitro results showed that incubation of lymphocytes with water or ethanol extracts of tiger nut tuber slightly increased the proliferation of B cells in response to LPS, a B cell mitogen. On the other hand, the same treatment induced marked increases in the $\mathrm{T}$ cell proliferation in response to ConA in a dose-dependent manner. Therefore, it seems that tiger nut exhibits selective effects on $\mathrm{T}$ lymphocytes; that is it inhibits the proliferation of the inflammatory lymphocytes, but increases the proliferation of naive lymphocytes. The mechanism mediating these opposing effects of tiger nut on the inflammatory and naïve lymphocytes needs further investigation. Further studies are also required to define the active ingredients of this promising plant. Taken together, the results of the present work highlight the nutritional benefits of tiger nut on the immune cells in health and diseases.

\section{REFERENCES}

1. Libby P. Multiple mechanisms of thrombosis complicating atherosclerotic plaques. Clin Cardiol 2000;23 Suppl 6:VI-3-7.

2. Greaves DR, Channon KM. Inflammation and immune responses in atherosclerosis. Trends Immunol 2002;23(11):535-41.

3. Harada LM, Carvalho MD, Passarelli M, Quintao EC. Lipoprotein desialylation simultaneously enhances the cell cholesterol uptake and impairs the reverse cholesterol transport system: in vitro evidences utilizing neuraminidase-treated lipoproteins and mouse peritoneal macrophages. Atherosclerosis 1998;139(1):65-75.

4. Daugherty A. Mouse models of atherosclerosis. Am J Med Sci 2002;323(1):3-10.

5. Grimsditch DC, Penfold S, Latcham J, Vidgeon-Hart M, Groot PH, Benson GM. C3H apoE(-/-) mice have less atherosclerosis than C57BL apoE(-/-) mice despite having a more atherogenic serum lipid profile. Atherosclerosis 2000;151(2):389-97.

6. Harrach-Ruprecht B, Kuchenhoff A, Robenek H. Interaction of apo E-containing lipoproteins with the LDL-receptor-related protein, LRP. Z Gastroenterol 1996;34 Suppl 3:122-3.

7. Rohdewald P. A review of the French maritime pine bark extract (Pycnogenol), a herbal medication with a diverse clinical pharmacology. Int J Clin Pharmacol Ther 2002;40(4):158-68.

8. Kyo E, Uda N, Kasuga S, Itakura Y. Immunomodulatory effects of aged garlic extract. $\mathrm{J}$ Nutr 2001;131(3s):1075S-9S.

9. Fischer S, Scheffler A, Kabelitz D. Stimulation of the specific immune system by mistletoe extracts. Anticancer Drugs 1997;8 Suppl 1:S33-7.

10. Salem ML, Hossain MS. Protective effect of black seed oil from Nigella sativa against murine cytomegalovirus infection. Int J Immunopharmacol 2000;22(9):729-40.

11. Salim EI, Fukushima S. Chemopreventive potential of volatile oil from black cumin (Nigella sativa L.) seeds against rat colon carcinogenesis. Nutr Cancer 2003;45(2):195-202.

12. Abuharfeil NM, Salim M, Von Kleist S. Augmentation of natural killer cell activity in vivo against tumour cells by some wild plants from Jordan. Phytother Res 2001;15(2):109-13.

13. Okladnikov I, Vorkel L, Trubachev I, Vlasova N, Kalacheva G. Inclusion of chufa in the human diet as a source of polyunsaturated fatty acids. Voprosy Pitaniia 1977;3:45-48.

14. Mokady SH, Dolev A. Nutritional evaluation of tubers of Cyperus esculenuts L. J Sci Fd Agric 1970;21:211-14. 
15. Shilenko M, Kalacheva G, Lisovskii G, Trubachev I. Chufa (Cyperus esculenuts) as a source of vegetable fat in seald life-support system. Kosm Biol Aviakosm Med 1979;13:70-74.

16. Emmanuel OA, Edward E. Nutritive value of a mixture of tigernut tubers (Cyperus esculenuts L.) and baobab seeds (Adansonia digitata L.). J Sci Food Agric 1984;35.

17. Nutrition AIo. Report of the American Institute of Nutrition and hoc committee on standards for nutritional studies. J Nutr 1997;107:1340-48.

18. Paigen B, Morrow A, Holmes PA, Mitchell D, Williams RA. Quantitative assessment of atherosclerotic lesions in mice. Atherosclerosis 1987;68(3):231-40.

19. Ni W, Tsuda Y, Sakono M, Imaizumi K. Dietary soy protein isolate, compared with casein, reduces atherosclerotic lesion area in apolipoprotein Edeficient mice. J Nutr 1998;128(11):1884-9.

20. Paulsson G, Zhou X, Tornquist E, Hansson GK. Oligoclonal $\mathrm{T}$ cell expansions in atherosclerotic lesions of apolipoprotein E-deficient mice. Arterioscler Thromb Vasc Biol 2000;20(1):10-7.

21. Osada J, Joven J, Maeda $N$. The value of apolipoprotein E-knockout mice for studying the effects of dietary fat and cholesterol on atherogenesis. Curr Opin Libid 2000;11:25-29.

22. Osuga J, Yonemoto M, Yamada N, Shimano H, Yagyu H, Ohashi K, et al. Cholesterol lowering in low density lipoprotein receptor knockout mice overexpressing apolipoprotein E. J Clin Invest 1998;102(2):386-94.

23. Nicholson AC, Febbraio M, Han J, Silverstein RL, Hajjar DP. CD36 in atherosclerosis. The role of a class B macrophage scavenger receptor. Ann N Y Acad Sci 2000;902:128-31; discussion 31-3.

24. Larkin L, Khachigian LM, Jessup W. Regulation of apolipoprotein $\mathrm{E}$ production in macrophages (review). Int J Mol Med 2000;6(3):253-8.

25. Rajavashisth T, Qiao JH, Tripathi S, Tripathi J, Mishra N, Hua M, et al. Heterozygous osteopetrotic (op) mutation reduces atherosclerosis in LDL receptor- deficient mice. J Clin Invest 1998;101(12):2702-10.

26. Koopman G, Keehnen RM, Lindhout E, Newman W, Shimizu Y, van Seventer GA, et al. Adhesion through the LFA-1 (CD11a/CD18)-ICAM-1 (CD54) and the VLA-4 (CD49d)-VCAM-1 (CD106) pathways prevents apoptosis of germinal center B cells. J Immunol 1994;152(8):3760-7.

27. Weitz-Schmidt G. Lymphocyte function-associated antigen-1 blockade by statins: molecular basis and biological relevance. Endothelium 2003;10(1):437.

28. Renier G, Mamputu JC, Serri O. Benefits of gliclazide in the atherosclerotic process: decrease in monocyte adhesion to endothelial cells. Metabolism 2003;52(8 Suppl 1):13-8.

29. Ganesh SK, Nass CM, Blumenthal RS. Antiatherosclerotic effects of statins: lessons from prevention trials. J Cardiovasc Risk 2003;10(3):155-9.

30. Hansson GK. Regulation of immune mechanisms in atherosclerosis. Ann N Y Acad Sci 2001;947:15765; discussion 65-6.

31. Hansson GK, Zhou X, Tornquist E, Paulsson G. The role of adaptive immunity in atherosclerosis. Ann N Y Acad Sci 2000;902:53-62; discussion 624.

32. Klimov AN, Denisenko AD, Popov AV, Nagornev VA, Pleskov VM, Vinogradov AG, et al. Lipoprotein-antibody immune complexes. Their catabolism and role in foam cell formation. Atherosclerosis 1985;58(1-3):1-15.

33. Zhou $X$, Nicoletti A, Elhage R, Hansson GK. Transfer of CD4(+) $\mathrm{T}$ cells aggravates atherosclerosis in immunodeficient apolipoprotein E knockout mice. Circulation 2000;102(24):291922.

34. Zhou X, Paulsson G, Stemme S, Hansson GK. Hypercholesterolemia is associated with a $\mathrm{T}$ helper (Th) $1 /$ Th2 switch of the autoimmune response in atherosclerotic apo E-knockout mice. J Clin Invest 1998;101(8):1717-25.

35. Zhou X, Stemme S, Hansson GK. Evidence for a local immune response in atherosclerosis. CD4+ T cells infiltrate lesions of apolipoprotein-E-deficient mice. Am J Pathol 1996;149(2):359-66.

36. Dansky HM, Charlton SA, Harper MM, Smith JD. $\mathrm{T}$ and $\mathrm{B}$ lymphocytes play a minor role in atherosclerotic plaque formation in the apolipoprotein E-deficient mouse. Proc Natl Acad Sci U S A 1997;94(9):4642-6.

37. Lutgens E, Cleutjens KB, Heeneman S, Koteliansky VE, Burkly LC, Daemen MJ. Both early and delayed anti-CD40L antibody treatment induces a stable plaque phenotype. Proc Natl Acad Sci U S A 2000;97(13):7464-9.

38. Melter M, Reinders ME, Sho M, Pal S, Geehan C, Denton MD, et al. Ligation of CD40 induces the expression of vascular endothelial growth factor by endothelial cells and monocytes and promotes angiogenesis in vivo. Blood 2000;96(12):3801-8.

39. Mahley RW, Rall SC, Jr. Apolipoprotein E: far more than a lipid transport protein. Annu Rev Genomics Hum Genet 2000;1:507-37.

40. Lutgens E, Daemen MJ. CD40-CD40L interactions in atherosclerosis. Trends Cardiovasc Med 2002;12(1):27-32. 